\title{
Effects of life-history traits and species distribution on genetic structure at maternally inherited markers in European trees and shrubs
}

Itziar Aguinagalde ${ }^{1}$, Arndt Hampe ${ }^{2,3}$, Aparajita Mohanty ${ }^{1}$, Juan Pedro

Martín $^{1}$, Jérôme Duminil ${ }^{2}$ and Rémy J. Petit ${ }^{2} *$

${ }^{1}$ Dpto. Biología, Escuela Técnica Superior de Ingenieros Agrónomos, Universidad Politécnica, Madrid, Spain, ${ }^{2}$ Institut National de la Recherche Agronomique, UMR Biodiversité, Gènes et Ecosystèmes, Cestas, France and ${ }^{3}$ Depto. de Biología Vegetal y Ecología, Universidad de Sevilla, Sevilla, Spain

\begin{abstract}
Aim To examine relationships between life-history traits, ecological and chorological characteristics of woody plant species and patterns of genetic differentiation among populations as assessed by chloroplast DNA (cpDNA) markers, and to compare them with patterns previously described from nuclear markers.
\end{abstract}

Location Europe.

Methods Data on cpDNA variation were compiled for 29 temperate European broad-leaved tree and shrub species. Six qualitative and three quantitative characters of the species were tested for their relationship with two parameters of genetic population differentiation $\left(\mathrm{G}_{\mathrm{ST}}\right.$ and $\left.\mathrm{N}_{\mathrm{ST}}\right)$. Both direct species comparisons and phylogenetically independent contrast analyses were performed.

Results When the phylogeny was not taken into account, five characters were significantly related to levels of population differentiation. The relationship disappeared in all but two cases (distribution type and seed mass) when analyses controlled for phylogenetic relationships among species.

Main conclusions The correlation between distribution type (boreal-temperate or temperate) and cpDNA differentiation of temperate European woody plant species suggests that their Quaternary history, in particular the location and isolation of their glacial refugia, is an important determinant of their present-day level of genetic structure. By contrast, the relationship between life-history traits and genetic differentiation at maternally inherited markers is weaker, especially when phylogenetic effects are controlled for.

Keywords

cpDNA, colonization, ecological strategy, phylogeography, quantitative parameters, seed dispersal, seed weight.
*Correspondence: Rémy J. Petit, INRA, UMR d'Arcachon, 33612 Cestas Cedex, France.

E-mail: petit@pierroton.inra.fr

\section{INTRODUCTION}

Life-history traits vary widely among plant species, and their relationships with patterns of genetic diversity have attracted the interest of population geneticists for over 25 years (e.g. Hamrick et al., 1979). Numerous correlations between ecological and life-history traits and levels of genetic variation have been reported by meta-analyses of the abundant plant allozyme literature. The characters tested for their relation to genetic variation have included life-form, breeding system, seed and pollen dispersal mechanism, mode of reproduction, successional status, as well as geographical range size and distribution type (Hamrick et al., 1979, 1992; Loveless \& Hamrick, 1984; Hamrick \& Godt, 1989, 1996). In fact, a recurrent question is whether life-history 'traits', i.e. measurable aspects of the phenotype affecting the demography of the 
species, are better suited to predict patterns of genetic variation than aspects related to the geographical and historical context into which species are evolving, such as the size or location of the distribution range. New comparative studies of genetic variation might help address this question.

Recently, diverse DNA-based molecular techniques have become standard tools for assessing patterns of genetic variation. But while allozyme studies provide a relatively high comparability of obtained patterns, most DNA-based analyses do not lend themselves easily to useful comparisons across species due to the much greater heterogeneity of techniques used. This heterogeneity (well illustrated by the flourishing number of acronyms in the field such as AFLP, RAPD, RFLP, SNP, SSR, etc.) has made it difficult to opt for a single standardized procedure to measure genetic diversity, which has in turn contributed to the scarcity of compilations of DNAbased studies of genetic variation, at least until recently (Nybom \& Bartish, 2000; Nybom, 2004). On the contrary, measures that estimate the proportion of total genetic diversity that is distributed among populations, such as Wright's fixation index $F_{\mathrm{ST}}$, are largely uncoupled from total diversity itself (see e.g. Petit et al., 1995). They are therefore well-suited for interspecific comparisons even when diversity itself cannot be compared across studies.

It is now widely accepted that comparative studies can suffer from 'pseudo-replication' when species are treated as statistically independent data points (e.g. Silvertown \& Dodd, 1996). This so-called TIP approach (because it directly compares extant species, situated at the tips of the phylogeny) is still used in interspecific comparisons of genetic variation in plants (e.g. Nybom, 2004), although it might produce overly optimistic or even biased results. Comparative analyses should take advantage of the accumulating knowledge on the phylogenetic relationships of taxa (Harvey \& Pagel, 1991), e.g. by using phylogenetically independent contrasts ('PIC'; Felsenstein, 1985). Such corrections would be particularly indicated when studying plant life-history traits, some of which are known to evolve slowly (e.g. Jordano, 1995), resulting in large phylogenetic inertia (defined as the tendency for traits to resist evolutionary change despite environmental perturbations; Edwards \& Naeem, 1993; Morales, 2000).

Although comparative statistical methods are increasingly used in ecology, we are aware of only one case where the authors have considered problems of non-independence of taxa while investigating genetic variation: Gitzendanner \& Soltis (2000) selected pairs of congeneric species to test if rare species have lower levels of diversity than widespread ones, thereby effectively controlling for phylogenetic dependence. However, such a procedure has a reduced power as only pairs of closely related species are contrasted (Ackerly, 2000).

Here, we explore relationships between genetic differentiation based on chloroplast DNA (cpDNA) and both lifehistory traits and ecological characteristics and distribution type of temperate European tree and shrub species using TIP and PIC analyses, the latter based on independent contrasts distributed over the whole phylogeny (Felsenstein, 1985), and not merely on pairs of related species, as in Gitzendanner \& Soltis (2000). In contrast to the nuclear genome examined by allozyme or DNA-based analyses, cpDNA is generally at least predominantly uniparentally inherited (in angiosperms most often maternally; Petit \& Vendramin, 2004). Hence, genetic structure at cpDNA markers should mostly depend on seedmediated gene flow, whereas genetic structure at nuclear markers depends on both seed- and pollen-mediated gene flow (Petit et al., 1993). As a consequence, a rather straightforward relationship of life-history traits related to seed dispersal or establishment with cpDNA differentiation might be expected, compared with the situation for nuclear markers (e.g. Hamrick \& Godt, 1989, 1996; Nybom \& Bartish, 2000; Nybom, 2004).

Two measures of genetic differentiation among populations were used: $\mathrm{G}_{\mathrm{ST}}$ and $\mathrm{N}_{\mathrm{ST}}$. The $\mathrm{G}_{\mathrm{ST}}$ is a commonly used parameter to assess the proportion of genetic diversity residing among populations (Nei, 1973). However, a more general parameter is the $\mathrm{N}_{\mathrm{ST}}$, which is similar to the $\mathrm{G}_{\mathrm{ST}}$ but considers additionally the similarities between molecular variants (Pons \& Petit, 1996). A comparison between both parameters allows one to make some inferences on historical population dynamics, as $\mathrm{N}_{\mathrm{ST}}$ should be larger than $\mathrm{G}_{\mathrm{ST}}$ if phylogenetically related variants are found in the same populations more often than expected by chance (i.e. $\mathrm{N}_{\mathrm{ST}}$ integrates a phylogeographical dimension, contrary to $\mathrm{G}_{\mathrm{ST}}$ ).

Although the species included in this study represent the majority of broad-leaved shrub and tree genera distributed across temperate Europe, their number is relatively small compared with the many hundred species used by Hamrick \& Godt $(1989,1996)$, and the power of our analyses is necessarily restricted. However, our data comprise the largest available multi-species set of cpDNA data for a single region. It has been obtained by similar analytical methods and thus allows a direct comparison of species. This comparison is further strengthened by the fact that most taxa have been collected mainly from the same set of 25 forests (Petit et al., 2003). This otherwise unachieved level of standardized sampling removes part of the variation in genetic parameters that arises from differences in the species sampling schemes. This statistical noise is an inherent problem of previous comparative studies that has been discussed (Hamrick \& Godt, 1996) but never controlled for. Finally, our study goes beyond most previous analyses by taking phylogenetic relationships between species into account.

\section{MATERIALS AND METHODS}

Life-history traits, ecology and distribution and their relationship with population differentiation

We analysed a total of six qualitative and three quantitative characteristics of the woody plants investigated. We selected those plant attributes that are predicted to be related to population genetic parameters (Loveless \& Hamrick, 1984; Hamrick \& Godt, 1989, 1996). However, we changed some of 
the traits investigated by these authors to account for the predominantly maternal inheritance of cpDNA. In particular, patterns of cpDNA variation are not affected by sexual reproduction but only by patterns of seed dispersal and of population establishment and extinction. In addition to previous studies, we aimed at exploring possible relationships between levels of genetic structure and the different components of a recently proposed system of plant species classification, the so-called 'leaf-height-seed plant ecology strategy scheme’ (LHS; Westoby, 1998). In the following, we specify the analysed characters and our hypotheses regarding their putative relationships with patterns of genetic population differentiation. Interactions between traits and patterns of seed flow or population establishment and extinction can be complex, and knowledge in this area is still fragmentary, so in some cases no unambiguous predictions could be made.

\section{Growth form}

Nuclear markers reveal typically lower degrees of amongpopulation differentiation in long-lived tree species (Hamrick \& Godt, 1989, 1996; Nybom, 2004). We checked if this trend is also detectable with cpDNA markers by assigning the species investigated to one of the three categories: tree, shrub and climber.

\section{Reproductive mode}

Vegetatively reproducing species were defined as those species able to propagate in this way, i.e. we excluded from this category in situ persistence through, e.g. resprouting from the stump. As previously mentioned, cpDNA genetic differentiation should reflect historical population establishments and extinctions. Species that are able to reproduce vegetatively can establish more easily, as they do not need to find a mate, so these species might be expected to have lower level of cpDNA differentiation. However, alternative scenarios can also be envisaged. For instance, species that recruit exclusively from seeds could experience higher seed-mediated gene flow (resulting in decreased cpDNA differentiation) than those that rely in part on vegetative multiplication for their reproduction. A clear prediction of the effect of reproductive mode on cpDNA differentiation is therefore difficult. In fact, no relationship with reproductive mode had been detected with allozyme markers by Hamrick \& Godt (1989).

\section{Pollination mode}

Chloroplast DNA is not transmitted through pollen in most angiosperms, but pollen limitation could limit the growth of establishing populations, because it restricts the reproductive output of plants at low density (Petit et al., 2004). Insectmediated pollination is more directional than wind pollination. Its advantage in low-density populations might therefore promote colonization events. On the contrary, islands are known to harbour a large share of wind-pollinated species (Carlquist, 1966), a pattern that suggests that establishment of wind-pollinated species is favoured in environments where pollinators are scarce. Depending on the presence or not of pollinating insects in the recipient community, establishment of plants having either mode of pollination might be facilitated. Here as well, predictions of levels of population differentiation are therefore difficult.

\section{Seed dispersal mode}

Different dispersal agents produce different levels of population differentiation at nuclear markers (Hamrick \& Godt, 1989, 1996; Nybom, 2004). As they determine patterns of seedmediated gene flow, they should be related to levels of cpDNA genetic structure. We distinguished seed dispersal by wind, by fruit-ingesting animals and by seed-caching animals, which were hypothesized to show decreasing levels of dispersal potential (in particular over long distances) and hence increasing levels of population differentiation.

\section{Successional status}

Patterns of population establishment and extinction vary considerably between species that are most common in early and intermediate successional plant communities and those that grow predominantly in late successional vegetation. We therefore assigned species to one of these two categories and predicted that population differentiation would be higher in late-successional species, although the opposite pattern had been demonstrated with nuclear markers (Hamrick \& Godt, 1989; Nybom, 2004).

\section{Distribution type}

Hamrick \& Godt (1989) observed that species with borealtemperate distribution tend to show lower values of population differentiation than species that are restricted to lower latitudes. We distinguished between boreal-temperate and temperate species in order to test if our data on cpDNA variation corroborate their findings.

\section{LHS strategy components}

The LHS framework of plant strategies considers three largely independent dimensions. These include gradients along which plant species can be positioned by the measurement of simple quantitative parameters (Westoby, 1998): the leaf mass per area-leaf lifespan gradient (L, quantified by the specific leaf area), the low stature-high stature gradient $(\mathrm{H}$, quantified by maximum plant height) and the seed mass-seed output gradient ( $\mathrm{S}$, quantified by seed mass). We determined these parameters for each species in order to test which of the three proposed plant trait dimensions is most tightly related to patterns of genetic population differentiation. For specific leaf 


\section{Aguinagalde et al.}

area we did not find empirical studies that would suggest any hypothesis. Plant height, however, should be directly related to genetic population structure. Local genetic differentiation occurs at a broader scale in trees compared with herbs (Linhart \& Grant, 1996), and high stature should facilitate seed dispersal, at least for wind- or gravity-dispersed seeds (Petit et al., 2004). A lower level of population differentiation is therefore predicted in taller species. Finally, relationships have been suggested between seed size and colonizing ability, whereby those species with small-sized seeds tend to have the highest colonizing potential. Indeed, according to Westoby (1998, p. 219), 'seed mass (as a surrogate for seed output per ground area occupied) is the best currently available predictor of the chance that an occupied site will disperse a propagule to an establishment opportunity'. Alternatively, Eriksson (2000) argued that species with medium-sized seeds within their communities would have the best probability to establish. We therefore tested if either of these categories of seeds exhibits lower levels of population differentiation.

\section{Data collection}

A total of 29 woody species with available information on cpDNA variation were included in the analyses (Table 1). We considered six categorical and three quantitative characters of the species and addressed their relationships with levels of population differentiation. Information on species life-history features, ecology and chorology was obtained from different sources including standard floras, botanical literature and ecological data bases (Tutin et al., 1964-80; Fitter \& Peat, 1994; Ellenberg, 1996). Such information is necessarily very simplified and is meant to represent the typical situation for the species. Some additional data on specific leaf area (SLA: leaf dry weight per unit of surface) were obtained from voucher specimens (10 per species) collected in the Devesa da Rogueira forest (Lugo Province, north-western Spain) using a computerized image analysis with a 'Summagraphics' MM1103 image scanner, Programme VIDS III. The objective here was to obtain comparable measures assuming that variation across sites is low compared with variation across taxa.

\section{Data analyses}

The program PERMUT (by R. J. Petit, available at http://www.pierroton.inra.fr/genetics/labo/Software/Permut/ index.html) was used to estimate the parameters of population subdivision, either taking into account $\left(\mathrm{N}_{\mathrm{ST}}\right)$ or not $\left(\mathrm{G}_{\mathrm{ST}}\right)$ similarities between haplotypes (Pons \& Petit, 1996), and testing the difference between both parameters through random permutation of haplotype identity (Burban et al., 1999). Note that the estimators of these parameters proposed by Pons \& Petit $(1995,1996)$ are based on a random model of population variation, instead of the fixed model procedure assumed by Nei \& Chesser (1983). Hence, the variation due to the sampling of populations is taken into consideration, allowing comparisons across species. As both indices range from 0 to +1 , data were arcsin square root transformed to improve normality before proceeding with further analyses.

In a first step, the TIP approach, we checked for differences between life-history categories in $\mathrm{G}_{\mathrm{ST}}$ or $\mathrm{N}_{\mathrm{ST}}$ mean values using Student's t-tests (with separate variance estimates) or one-way anovas. In the case of the quantitative traits of the LHS concept (SLA, plant height and seed mass) we used Pearson correlation coefficients to assess their associations with $\mathrm{G}_{\mathrm{ST}}$ / $\mathrm{N}_{\text {ST }}$ values. All three variables were log-transformed prior to analyses. One of our hypotheses suggested a curvilinear relationship between seed mass and $\mathrm{G}_{\mathrm{ST}} / \mathrm{N}_{\mathrm{ST}}$ with the lowest values occurring at intermediate seed sizes (see above); we therefore calculated the deviations of specific seed sizes from the overall mean, and used this parameter along with the original one for the correlation analysis, resulting in a total of four quantitative variables studied. We accounted for the multiplicity of tests by assuming statistical significance at a $1 / 40.01$. Given the largely exploratory character and the relatively low sample size of our study, we deemed this level justified, although it is somewhat higher than the very conservative one obtained by Bonferroni correction (a $1 / 40.005$ for 10 tests).

The subsequent comparative analysis was carried out using PICs as implemented in Compare 4.5 (Martins, 2003). The categories of most life-history traits were coded as dummy variables ( 0 or 1$)$. The seed dispersal mode contained more than two categories; nevertheless, only one type of contrast was considered, by pooling all categories except wind together. The super-tree (Bininda-Emonds et al., 1999) used for these analyses was based mostly on the angiosperm phylogeny of Soltis et al. (2000), on which the missing species had been grafted according to other phylogenetic studies (Chen et al., 1999; Evans, 1999) (Fig. 1). No information on branch length was available for inclusion in the PIC analyses, given the various sources of information used. According to Ackerly (2000), using equal branch lengths should not significantly bias the results.

\section{RESULTS}

The average $G_{\text {ST }}$ value over all species was 0.52 , but interspecific variation was large (Table 2). For instance, Salix caprea had most cpDNA variation distributed within populations ( $G_{\text {ST }} 1 / 40.09$ ), whereas Carpinus betulus had cpDNA polymorphisms almost completely distributed among populations $\left(G_{S T} 1 / 40.97\right)$. Values for $N_{S T}$ were significantly larger than the corresponding $G_{\mathrm{ST}}$ values in 11 of 29 species, thus indicating the existence of a phylogeographical structure. This phenomenon was significantly more common among species with an above-average level of population differentiation than among species with a below-average level (Fig. 2; v $v^{2} 1 / 48.0$, d.f. $1 / 4$ 1, P $1 / 4$ 0.005).

The TIP analyses revealed significant differences among groups for four of the six tested categorical life-history traits, whereas a further trait was marginally significant (Table 2). 
Table 1 Life-history traits and parameters of genetic population differentiation of the 29 temperate European broad-leaved tree and shrub species included in the analyses

Seed Distribution Successional SLA Height Seed mass

Total no. Mean no. Total no.

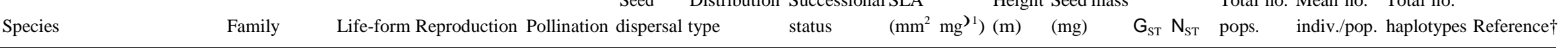

Aceraceae $\mathrm{T} \quad \mathrm{S}-\mathrm{T}$

$\begin{array}{ll}\text { W } & \text { T } \\ \text { W } & \text { T } \\ \text { W } & \text { T } \\ \text { W } & \text { BT } \\ \text { W } & \text { BT } \\ \text { W } & \text { BT } \\ \text { W } & \text { T } \\ \text { AC } & \text { T } \\ \text { AI } & \text { T }\end{array}$

$\begin{array}{ll}\text { EM } & 23.2 \\ \text { L } & 19.6 \\ \text { EM } & 14.0 \\ \text { EM } & 33.4 \\ \text { EM } & 14.4 \\ \text { EM } & 11.6 \\ \text { L } & 19.5 \\ \text { EM } & 21.3 \\ \text { EM } & 17.1\end{array}$

Aceraceae $T$

Acer pseudoplatanus L.

Betulaceae $\mathrm{T}$

Betula pendula Roth.

Betulaceae $\mathrm{T}$

Betula pube

Betulaceae $\mathrm{T}$

Ericaceae $\mathrm{S}$

Betulaceae $\mathrm{T}$

Betulaceae S

(Poiret) DC

Crataegus monogyna Jacq.

Cytisus scoparius L.

Fagus sylvatica $\mathrm{L}$.

$\begin{array}{lll}\text { Rosaceae } & \mathrm{S} & \mathrm{S} \\ & \mathrm{S} & \mathrm{S}\end{array}$

Frangula alnus ssp.

Fabaceae $\mathrm{S}$

AI $\quad \mathrm{T}$

Fagaceae $T$

AC $\quad$ T

Fraxinus angustifolia Vahl.

Fraxinus excelsior L.

Hedera helix s.l.

Rhamnaceae $\mathrm{S} S$

Ilex aquifolium L.

Populus tremula $\mathrm{L}$.

Prunus avium L.

Prunus spinosa L.

Quercus robur L.

Rubus fruticosus group

Salix caprea L.

Sorbus aria L.

$\begin{array}{lll}\text { Oleaceae } & T & \mathrm{~S} \\ \text { Oleaceae } & \mathrm{T} & \mathrm{S}\end{array}$

Araliaceae C SV

Aquifoliaceat $\mathrm{T}$

Salicaceae $\mathrm{T}$

Rosaceae $T$

Rosaceae $\mathrm{S}$

Fagaceae $\mathrm{T}$

Rosaceae

Salicaceae $\mathrm{T}$

Rosaceae

Sorbustorminalis (L.) Crantz Rosaceae

Tilia cordata Mill.

Tilia platyphyllos Scop.

Tiliaceae

Ulmus glabra Huds.

Tiliaceae

Ulmus minor Mill.

Ulmaceae T

$\begin{array}{cclll}15 & 32.0 & 0.70 & 0.73 & 18 \\ 30 & 30.6 & 0.67 & 0.75^{*} & 21 \\ 20 & 1.3 & 0.82 & 0.90^{*} & 28 \\ 25 & 0.2 & 0.42 & 0.44 & 23 \\ 20 & 0.2 & 0.30 & 0.26 & 20 \\ 0.6 & 0.03 & 0.47 & 0.44 & 23 \\ 30 & 41.1 & 0.97 & 0.97 & 35 \\ 6 & 1080.0 & 0.90 & 0.95^{*} & 25 \\ 10 & 60.1 & 0.34 & 0.34 & 9\end{array}$

$\begin{array}{rrl}10.2 & 19 & 1 \\ 9.7 & 22 & 1 \\ 9.3 & 12 & 2 \\ 9.3 & 9 & 3 \\ 8.1 & 10 & 4 \\ 8.3 & 12 & 5 \\ 6.8 & 6 & 6 \\ 9.3 & 5 & 7 \\ 5.2 & 3 & 8\end{array}$

Life form: T 1/4 tree, S 1/4 shrub, C $1 / 4$ climber; reproduction: S 1/4 exclusively sexual, SV 1/4 sexual and vegetative; pollination: B 1/4 biotic, A $1 / 4$ abiotic; seed dispersal: W $1 / 4$ wind, AC $1 / 4$ animal-cached, AI $1 / 4$ animal-ingested, $\mathrm{G}^{1 / 4}$ gravity; distribution type: T 1/4 temperate, BT $1 / 4$ boreal-temperate; succession status: EM $1 / 4$ early intermediate, $\mathrm{L}^{1 / 4}$ late.

$* \mathrm{~N}_{\mathrm{ST}}>\mathrm{G}_{\mathrm{ST}}$ at $\mathrm{P}<0.05$.

†1: Bittkau (2002), 2: Petit et al. (2003), 3: Palmé et al. (2003a), 4: Palmé et al. (2004), 5: Rendell \& Ennos (2002), 6: Grivet \& Petit (2003), 7: Palmé \& Vendramin (2002), 8: Fineschi et al. (2004), 9: Aguinagalde et al. (2002), 10: Hampe et al. (2003; only the nominated subspecies was included), 11: Vendramin, G.G. (CNR, Florence), unpublished data, 12: Heuertz et al. (2004), 13: Grivet \& Petit (2002), 14: Rendell \& Ennos (2003), 15: Mohanty et al. (2001), 16: Mohanty et al. (2002), 17: Petit \& Grivet (2002), 18: Palmé et al. (2003b), 19: Musch, B. (ONF, Orléans), unpublished data, 20: Oddou-Muratorio

et al. (2001), 21: Fineschi et al. (2003), 22: Fineschi, S. (CNR, Florence), unpublished data. 


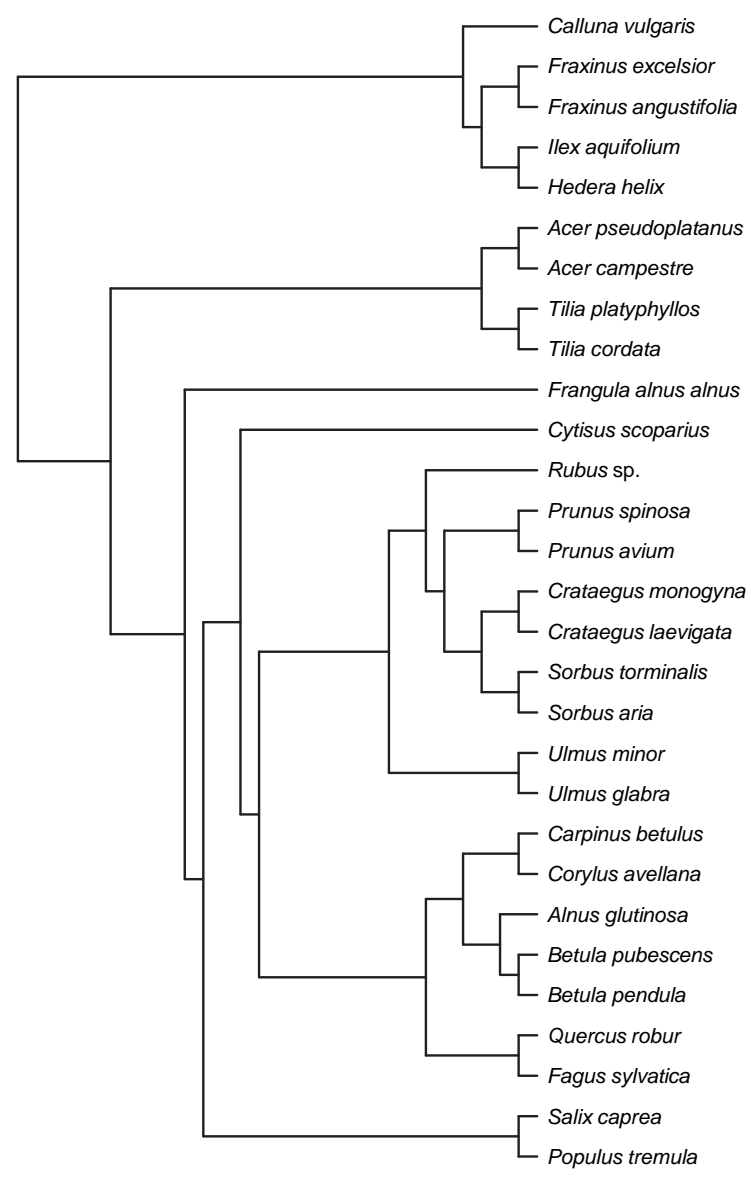

Figure 1 Phylogenetic super-tree of the 29 species included in the phylogenetically independent contrast analyses.
One of the quantitative traits (seed mass) was likewise marginally related to $G_{S T}$ and $N_{S T}$ (Pearson $r^{1 / 4} 0.42$, P 1/4 0.024; Table 3). Only two of the previous relationships remained significant after accounting for phylogenetic relations of species. Taxa with a boreal-temperate distribution as well as those with lower seed mass had a lower $G_{S T}$ and $N_{S T}$ than taxa with an exclusively temperate distribution or with a larger seed mass (Table 3).

\section{DISCUSSION}

This study relied on a relatively small number of taxa in comparison with the more than one thousand species used by Hamrick \& Godt (1996), and the power of our analyses is necessarily restricted. Despite the limited data set and the exploratory nature of this study, several important conclusions could be drawn.

\section{Effects of phylogeny upon observed trends}

Many of the relationships between life-history traits and genetic parameters that were significant in the TIP analyses vanished once we controlled for phylogenetic relationships among taxa. This does of course not mean that the examined traits are necessarily unrelated to levels of population differentiation. However, our results indicate that the more conservative estimates generated by the correction for phylogenetic pseudoreplication require a larger sample size (ideally from a broad set of families) than currently available, if we wish to detect significant relationships between the examined parameters. Our results also suggest that some previously

\begin{tabular}{lcclcc}
\hline Trait & $\mathrm{n}$ & $\mathrm{G}_{\mathrm{ST}}(\mathrm{SE})$ & $\mathrm{P}$ & $\mathrm{N}_{\mathrm{ST}}(\mathrm{SE})$ & $\mathrm{P}$ \\
\hline Life form & & & 0.39 & & 0.30 \\
$\quad$ Tree & 19 & $0.55(0.06)$ & & $0.60(0.07)$ & \\
$\quad$ Shrub & 9 & $0.46(0.07)$ & & $0.49(0.08)$ & \\
Reproduction & & & 0.003 & & 0.03 \\
$\quad$ Sexual & 17 & $0.63(0.06)$ & & $0.66(0.06)$ & \\
$\quad$ Sexual and asexual & 12 & $0.38(0.05)$ & & $0.45(0.07)$ & \\
$\quad$ Pollination & & & 0.02 & & 0.02 \\
$\quad$ Biotic & 17 & $0.43(0.04)$ & & $0.47(0.05)$ & \\
$\quad$ Abiotic & 12 & $0.66(0.08)$ & & $0.71(0.08)$ & \\
Seed dispersal & & & 0.01 & & \\
$\quad$ Wind & 15 & $0.56(0.07)$ & & $0.62(0.07)$ & \\
$\quad$ Animal ingested & 10 & $0.38(0.04)$ & & $0.42(0.06)$ & \\
$\quad$ Animal cached & 3 & $0.83(0.05)$ & & $0.83(0.08)$ & \\
Successional status & & & 0.001 & & \\
$\quad$ Early intermediate & 17 & $0.41(0.05)$ & & $0.43(0.06)$ & \\
$\quad$ Late & 12 & $0.69(0.05)$ & & $0.77(0.04)$ & \\
Distribution type & & & 0.002 & & \\
$\quad$ Temperate & 22 & $0.60(0.05)$ & & $0.66(0.05)$ & \\
$\quad$ Boreal-temperate & 7 & $0.30(0.06)$ & & $0.29(0.05)$ & \\
\hline
\end{tabular}

$\mathrm{G}_{\mathrm{ST}}$ and $\mathrm{N}_{\mathrm{ST}}$ values indicate category means with standard errors in brackets. Bold P-values indicate significant differences according to t-tests or one-way anova after correction for multiple testing (a $1 / 40.01)$.

life-history traits and levels of genetic population differentiation in temperate European broad-leaved tree and shrub species 


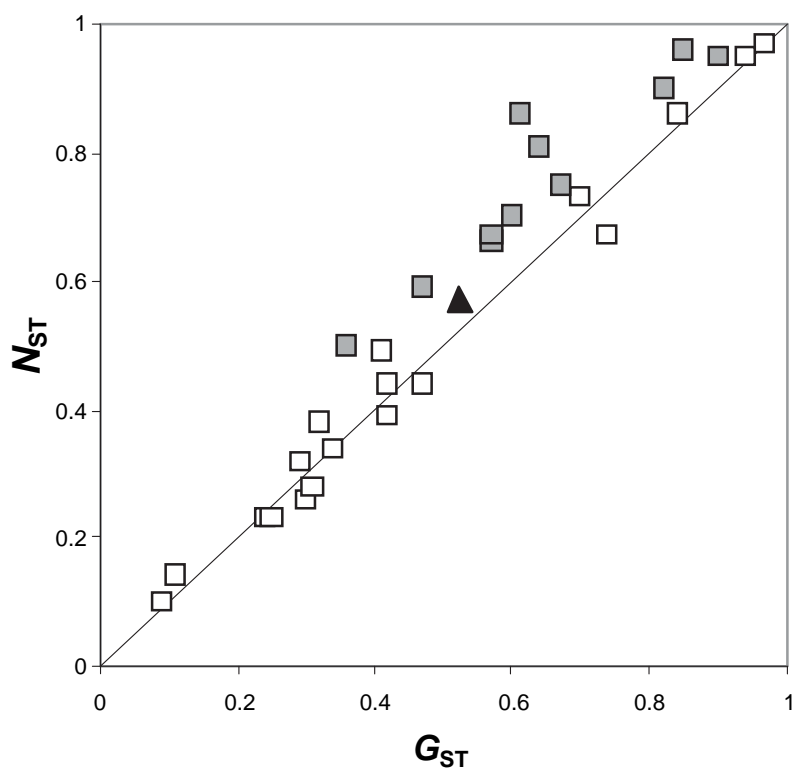

Figure 2 Evidence for phylogeographical structure in temperate European woody taxa: $\mathrm{N}_{\mathrm{ST}}$ as a function of $\mathrm{G}_{\mathrm{ST}}$. Filled squares indicate species for which $N_{S T}>G_{S T}$ (at $P<0.05$; see Table 1 for the complete list). Dark grey triangle: average over all species.

reported and widely accepted relationships obtained by TIP analyses (e.g. Hamrick \& Godt, 1989) should be interpreted with caution unless they are validated by studies that account for the phylogenetic relationships of the analysed species (see also Gitzendanner \& Soltis, 2000). The problem is aggravated by the fact that certain model taxa are typically overrepresented in population genetics compilations. Furthermore, these compilations have included not only multiple species from a few genera but also multiple entries involving the same species (e.g. Hamrick \& Godt, 1989; Nybom, 2004), which could exacerbate this problem. In fact, numerous recent re-examinations of data sets have invalidated or at least tempered previous evolutionary interpretations of ecological patterns obtained by TIP analyses (e.g. Ackerly \& Reich, 1999; Bolmgren et al., 2003). Life-history parameters might be particularly prone to readjustments given their strong phylogenetic inertia (Jordano, 1995).

As an illustration of a case where a PIC analysis might help, consider Hamrick \& Godt (1989) finding that both gymnosperms and boreal-temperate species have a low level of differentiation compared with angiosperms and species distributed at lower latitudes. As gymnosperms are overrepresented among high latitude species, it remained unclear which of the two parameters is primarily responsible for the observed trend using a TIP approach. A PIC analysis might have solved the problem. In addition, such an approach should be more powerful than the data-demanding procedure consisting of analysing trait combinations on the basis of direct comparisons among group means (Hamrick \& Godt, 1996).

One hypothesis of this work was that plant ecological strategies, such as those outlined in the LHS scheme (Westoby, 1998), might help identify relevant traits influencing population genetic structure. We found that seed weight is related with the level of genetic structure as assessed with maternally inherited markers. As seed weight is also related to seed output and to other aspects of the ecological strategies of plants, interpreting this relation is not straightforward. However, our study does not support the idea that medium-sized seeds within their communities tend to have the highest colonizing potential, as suggested by Eriksson (2000). The cpDNA population genetic structure of temperate and boreal-temperate plants is unlikely to reflect equilibrium between current patterns of gene flow and genetic drift in contemporary plant communities but should instead still reflect the modalities of post-glacial colonization (Le Corre et al., 1997; Petit et al., 1997; and see below). At that time recipient plant communities were very different and competition was probably less stringent than in present-day communities. As a consequence, a species dispersal ability (in terms of both seed production and
Table 3 Pearson coefficients of correlation between life-history traits and parameters of genetic population differentiation according to direct (TIP) or phylogenetically independent contrast (PIC) analyses

\begin{tabular}{|c|c|c|c|c|}
\hline \multirow[b]{2}{*}{ Trait } & \multicolumn{2}{|l|}{ TIP } & \multirow{2}{*}{$\begin{array}{l}\text { PIC } \\
\mathrm{G}_{\mathrm{ST}}\end{array}$} & \multirow[b]{2}{*}{$\mathrm{N}_{\mathrm{ST}}$} \\
\hline & $\mathrm{G}_{\mathrm{ST}}$ & $\mathrm{N}_{\mathrm{ST}}$ & & \\
\hline Life form & - & - & 0.14 & 0.12 \\
\hline Reproduction & - & - & 0.31 & 0.19 \\
\hline Pollination & - & - & 0.33 & 0.36 \\
\hline Seed dispersal $\dagger$ & - & - & ) 0.09 & 0.08 \\
\hline Successional status & - & - & 0.38 & 0.39 \\
\hline Distribution type & - & - & $0.63^{* *}$ & $0.66^{* *}$ \\
\hline Log specific leaf area & 0.11 & 0.07 & 0.15 & 0.14 \\
\hline Log height & 0.22 & 0.27 & 0.25 & 0.31 \\
\hline Log seed mass & $0.42 \ddagger$ & $0.43 \ddagger$ & $0.49 *$ & $0.50 *$ \\
\hline Divergence from mean log seed mass & 0.01 & 0.07 & 0.10 & 0.09 \\
\hline
\end{tabular}

Significant values (at a $1 / 40.01$ ) are: $* \mathrm{P}<0.01,{ }^{*} \mathrm{P}<0.001$.

†Only plants with wind-dispersed seeds were compared with the other categories to limit the number of tests and because of limited sample sizes in some categories. $\ddagger$ TIP correlation marginally significant at P 1/4 0.024 . 
subsequent transport) might have played a more important role than features related to recruitment (such as seed provisioning).

\section{Distribution type and level of cpDNA differentiation}

Most life-history traits examined did not demonstrate relationships with levels of cpDNA population differentiation after controlling for phylogenetic non-independence, although some of them (e.g. seed dispersal mode) were expected to show a straightforward relation to $\mathrm{G}_{\mathrm{ST}}$ or $\mathrm{N}_{\mathrm{ST}}$. Instead, the strongest relationship with $\mathrm{G}_{\mathrm{ST}} / \mathrm{N}_{\mathrm{ST}}$ involved the global distribution type of the species. Taxa with boreal-temperate distribution have significantly lower $\mathrm{G}_{\mathrm{ST}}$ and $\mathrm{N}_{\mathrm{ST}}$ values than species whose current distribution range is restricted to temperate Europe (see Table 2; mean $\mathrm{G}_{\mathrm{ST}} 1 / 40.36$ instead of 0.59 ; mean $\mathrm{N}_{\mathrm{ST}} 1 / 40.28$ instead of 0.66 ). Our results corroborate trends previously observed for allozyme markers (Hamrick \& Godt, 1989; Hamrick et al., 1992). However, in these earlier analyses, the species group with boreal-temperate distribution contained mostly conifers, which were not included in our study, so parallels should be drawn with caution.

Our results suggest that boreal-temperate species share one or several features which are both independent of their phylogenetic relationships and closely related to present-day patterns of cpDNA variation. In the geographical context of the present study, the current distribution range of species is related to their range during the last glacial maximum. Many taxa distributed today over the boreal regions of Europe survived the last glacial maximum across much of southern Europe, while most temperate tree species were restricted to isolated refugia in the Mediterranean Basin (Willis \& Niklas, 2004). This isolation with negligible gene flow between disjunct populations at time scales of $10^{6}$ years resulted in the formation of distinct cpDNA lineages that can still be traced and produced the phylogeographical structure currently observed in many temperate European woody species (see also Petit et al., 2003). In contrast, species of the boreal-temperate group were probably geographically less restricted and isolated during glacial maxima, which would give rise both to stronger dynamics of population establishments and extinctions, as well

as to greater seed-mediated gene flow between existing populations. These processes could account for the stronger relationship of $\mathrm{N}_{\mathrm{ST}}$ than $\mathrm{G}_{\mathrm{ST}}$ with distribution type, as only $\mathrm{N}_{\mathrm{ST}}$ includes a phylogenetic dimension. In other words, the Quaternary history of species could constitute a more determinant factor to account for current patterns of subdivision of cpDNA variation in temperate European tree and shrub species than life historical attributes.

Of course, woody species with a range extending into the boreal region probably do not represent a random sample of woody taxa. In particular, they could possess traits promoting high vagility (Dynesius \& Jansson, 2000; Hampe \& Bairlein, 2000), such as a small seed size or short generation turnover. This non-randomness is further supported by recent analyses indicating that there has been a high degree of ecological determinism in the fate of European Pliocene tree genera in response to past climate changes (Svenning, 2003). Such adaptations could be subtle and difficult to measure or classify and could covary with the current distribution range and latitudinal limits of the species. Clearly, disentangling the effects of history and genetic determinism on population genetic structure remains a challenging task for the future. This task should, however, be facilitated by a better understanding of the ever-increasing number of population genetic surveys, thanks to the use of existing, but still underutilized, comparative methods.

\section{CONCLUSION}

Life-history traits have high heritability and strong phylogenetic inertia (Jordano, 1995; Mazer \& LeBuhn, 1999). Direct cross-species comparisons (TIPS) of genetic diversity parameters as carried out for over 20 years appear to yield overly optimistic results. The consideration of phylogenetic inertia and the use of appropriate statistical methods to control for it should result in more conservative and unbiased estimates in the future. Now that plant phylogenies useful for comparative approaches are becoming increasingly available (e.g. Soltis et al., 1999), gathering population genetic data in publicly accessible data bases should become a priority if we want the independent efforts of many teams investigating genetic diversity of plant and animal species to be fully understood in the future.

\section{ACKNOWLEDGEMENTS}

The research was supported by the EC research program FAIR5-CT97-3795 to I. A. and to R. J. P. and by a grant from the Bureau des Ressources Génétiques to R. J. P. We thank our CYTOFOR colleagues (C. Bittkau, R. Ennos, S. Fineschi, D. Grivet, M. Lascoux, G. Müller-Starck, B. Musch, A. Palmé, S. Rendell, G. G. Vendramin) for allowing us to use their results. A. H. received financial support from the FPI grant PB98-1144 of the Spanish Ministry of Science and Technology.

\section{REFERENCES}

Ackerly, D.D. (2000) Taxon sampling, correlated evolution, and independent contrasts. Evolution, 54, 1480-1492.

Ackerly, D.D. \& Reich, P.B. (1999) Convergence and correlations among leaf size and function in seed plants: a comparative test using independent contrasts. American Journal of Botany, 86, 1272-1281.

Aguinagalde, I., Rebordinos, I., Mohanty, A. \& Martín, J.P. (2002) Chloroplast DNA diversity in the wild shrub Cytisus scoparius L. (Leguminosae). Israel Journal of Plant Sciences, 50, 1-9.

Bininda-Emonds, O., Gittleman, J. \& Purvis, A. (1999) Building large trees by combining phylogenetic information: a complete phylogeny of the extant Carnivora (Mammalia). 
Biological Review of the Cambridge Philosophical Society, 74, 143-175.

Bittkau, C. (2002) Charakterisierung der genetischen Variation europäischer Populationen von Acer spp. und Populus tremula auf der Basis der Chloroplasten-DNA: Rückschlüsse auf die postglaziale Ausbreitung und Differenzierung forstlicher Provenienzen. Dissertation Technische, Universität München, Wissenschaftszentrum Weihenstephan.

Bolmgren, K., Eriksson, O. \& Linder, H.P. (2003) Contrasting flowering phenology and species richness in abiotically and biotically pollinated angiosperms. Evolution, 57, 2001-2011.

Burban, C., Petit, R.J., Carcreff, E. \& Jactel, H. (1999) Rangewide variation of the maritime pine bast scale Matsucoccus feytaudi Duc. (Homoptera: Matsucoccidae) in relation to the genetic structure of its host. Molecular Ecology, 8, 15931602.

Carlquist, S. (1966) The biota of long-distance dispersal. IV. Genetic systems in the floras of oceanic islands. Evolution, 20, 433-455.

Chen, Z.D., Manchester, S.R. \& Sun, H.Y. (1999) Phylogeny and evolution of the Betulaceae as inferred from DNA sequences, morphology, and paleobotany. American Journal of Botany, 86, 1168-1181.

Dynesius, M. \& Jansson, R. (2000) Evolutionary consequences of changes in species' geographical distributions driven by Milankovitch climate oscillations. Proceedings of the National Academy of Sciences of the USA, 97, 9115-9120.

Edwards, S.V. \& Naeem, S. (1993) The phylogenetic component of cooperative breeding in perching birds. American Naturalist, 141, 754-789.

Ellenberg, H. (1996) Vegetation Mitteleuropas mit den Alpen, 5 th edn. Ulmer, Stuttgart.

Eriksson, O. (2000) Seed dispersal and colonization ability of plants - assessment and implications for conservation. Folia Geobotanica, 35, 115-123.

Evans, R. (1999) http://www.botany.utoronto.ca/faculty/dick inson/rosaceaeevolution/phylogeny.html.

Felsenstein, J. (1985) Phylogeny and the comparative method. The American Naturalist, 125, 1-15.

Fineschi, S., Salvini, D., Taurchini, D., Carnevale, S. \& Vendramin, G.G. (2003) Chloroplast DNA variation of Tilia cordata Mill. Canadian Journal of Forest Research, 33, 25032508.

Fineschi, S., Salvini, D., Turchini, D., Pastorelli, R., Vendramin, G.G. (2004) Genetic diversity and introgression in Crataegus monogyna Jacq. and C. laevigata (Poir.) DC. (Rosaceae, Maloideae) in European forests. Plant Systematics and Evolution, in press.

Fitter, A.H. \& Peat, H.J. (1994) The ecological flora database. Journal of Ecology, 82, 415-425.

Gitzendanner, M.A. \& Soltis, P.S. (2000) Patterns of genetic variation in rare and widespread plant congeners. American Journal of Botany, 87, 783-792.

Grivet, D. \& Petit, R.J. (2002) Phylogeography of the common ivy (Hedera sp.) in Europe: genetic differentiation through space and time. Molecular Ecology, 11, 1351-1362.
Grivet, D. \& Petit, R.J. (2003) Chloroplast DNA phylogeography of the hornbeam in Europe: evidence for a bottleneck at the outset of postglacial colonization. Conservation Genetics, 4, 47-56.

Hampe, A. \& Bairlein, F. (2000) Modified dispersal-related traits in disjunct populations of bird-dispersed Frangula alnus (Rhamnaceae): a result of its Quaternary distribution shifts? Ecography, 23, 603-613.

Hampe, A., Arroyo, J., Jordano, P. \& Petit, R.J. (2003) Rangewide phylogeography of a bird-dispersed Eurasian shrub: contrasting Mediterranean and temperate glacial refugia. Molecular Ecology, 12, 3415-3426.

Hamrick, J.L. \& Godt, M.J.W. (1989) Allozyme diversity in plant species. Plant population genetics, breeding and genetic resources (ed. by H.D. Brown, M.T. Clegg, A.L. Kahler and B.S. Weir), pp. 43-64. Sinauer Associates, Sunderland, MA, USA.

Hamrick, J.L. \& Godt, M.J.W. (1996) Effects of life history traits on genetic diversity in plant species. Philosophical Transactions of the Royal Society of London Series B, 351, 1291-1298.

Hamrick, J.L., Linhart, Y.B. \& Mitton, J.B. (1979) Relationships between life-history characteristics and electrophoretically detectable genetic variation in plants. Annual Review of Ecology and Systematics, 10, 173-200.

Hamrick, J.L., Godt, M.J.W. \& Sherman-Broyles, S.L. (1992) Factors influencing levels of genetic diversity in woody plant species. New Forests, 6, 95-124.

Harvey, P.H. \& Pagel, M.D. (1991) The comparative method in evolutionary biology. Oxford University Press, Oxford, UK.

Heuertz, M., Fineschi, S., Anzidei, M., Pastorelli, R., Salvini, D., Paule, L., Frascaria-Lacoste, N., Hardy, O.J., Vekemans, X. \& Vendramin, G.G. (2004) Chloroplast DNA variation and postglacial recolonisation of common ash (Fraxinus excelsior L.) in Europe. Molecular Ecology, 13, 3437-3452.

Jordano, P. (1995) Angiosperm fleshy fruits and seed dispersers: a comparative analysis of adaptation and constraints in plant-animal interactions. The American Naturalist, 145, 163-191.

Le Corre, V., Machon, N., Petit, R.J. \& Kremer, A. (1997) Colonisation with long-distance seed dispersal and genetic structure of maternally inherited genes in forest trees: a simulation study. Genetical Research, Cambridge, 69, 117125.

Linhart, Y.B. \& Grant, M.C. (1996) Evolutionary significance of local genetic differentiation in plants. Annual Review of Ecology and Systematics, 27, 237-277.

Loveless, M.D. \& Hamrick, J.L. (1984) Ecological determinants of genetic structure in plant populations. Annual Reviews of Ecology and Systematics, 15, 65-95.

Martins, E.P. (2003) COMPARE 4.5: statistical analysis of comparative data. Computer programs distributed by the author (http://www.compare.bio.indiana.edu).

Mazer, S.J. \& LeBuhn, G. (1999) Genetic variation in lifehistory traits: heritability estimates within and genetic differentiation among populations. Life history evolution 
in plants (ed. by T.O. Vuorisalo and P.K. Mutikainen), pp. 85-173. Kluwer Academic Publishers, Dordrecht, the Netherlands.

Mohanty, A., Martín, J.P. \& Aguinagalde, I. (2001) A population genetic analysis of chloroplast DNA in wild populations of Prunus avium L. in Europe. Heredity, 87, 421-427.

Mohanty, A., Martín, J.P. \& Aguinagalde, I. (2002) A population genetic analysis of chloroplast DNA in Prunus spinosa (Rosaceae) populations in Europe. American Journal of Botany, 89, 1223-1228.

Morales, E. (2000) Estimating phylogenetic inertia in Tithonia (Asteraceae): a comparative approach. Evolution, 54, 475484.

Nei, M. (1973) Analysis of gene diversity in subdivided populations. Proceedings of the National Academy of Sciences of the USA, 70, 3321-3323.

Nei, M. \& Chesser, R.K. (1983) Estimation of fixation indices and gene diversities. Annals of Human Genetics, 47, 253-257.

Nybom, H. (2004) Comparison of different nuclear DNA markers for estimating intraspecific genetic diversity in plants. Molecular Ecology, 13, 1143-1155.

Nybom, H. \& Bartish, I.V. (2000) Effects of life history traits and sampling strategies on genetic diversity estimates obtained with RAPD markers in plants. Perspectives in Plant Ecology, Evolution and Systematics, 3, 93-114.

Oddou-Muratorio, S., Petit, R.J., Le Guerroué, B., Guesnet, D. \& Demesure, B. (2001) Pollen- versus seed-mediated gene flow in a scattered forest tree species. Evolution, 55, 11231135.

Palmé, A.E. \& Vendramin, G.G. (2002) Chloroplast DNA variation, postglacial recolonization and hybridization in hazel, Corylus avellana. Molecular Ecology, 11, 1769-1780.

Palmé, A.E., Su, Q., Rautenberg, A., Manni, F. \& Lascoux, M. (2003a) Postglacial recolonisation and cpDNA variation of silver birch, Betula pendula. Molecular Ecology, 12, 201-212.

Palmé, A.E., Semerikov, V. \& Lascoux, M. (2003b) Absence of geographical structure of chloroplast DNA in sallow, Salix caprea L. Heredity, 91, 465-471.

Palmé, A.E., Su, Q., Palsson, S. \& Lascoux, M. (2004) Extensive sharing of chloroplast haplotypes among European birches indicates hybridization among Betula pendula, B. pubescens and B. nana. Molecular Ecology, 13, 167-178.

Petit, R.J. \& Grivet, D. (2002) Optimal randomization strategies when testing the existence of a phylogeographic structure. Genetics, 161, 469-471.

Petit, R.J. \& Vendramin, G.G. (2005) Plant phylogeography based on organelle markers: an introduction. Phylogeography in southern European refugia: evolutionary perspectives on the origins and conservation of European biodiversity (ed. by S. Weiss and N. Ferrand). Kluwer, Dordrecht, the Netherlands, in press.

Petit, R.J., Kremer, A. \& Wagner, D.B. (1993) Finite island model for organelle and nuclear genes in plants. Heredity, 71, 630-641.
Petit, R.J., Bahrman, N. \& Baradat, P. (1995) Comparison of genetic differentiation in maritime pine (Pinus pinaster Ait.) estimated using isozyme, total protein and terpenic loci. Heredity, 75, 382-389.

Petit, R.J., Pineau, E., Demesure, B., Bacilieri, R., Ducousso, A. \& Kremer, A. (1997) Chloroplast DNA footprints of postglacial recolonisation by oaks. Proceedings of the National Academy of Sciences of the USA, 94, 9996-10001.

Petit, R.J., Aguinagalde, I., de Beaulieu, J.L., Bittkau, C., Brewer, S., Cheddadi, R., Ennos, R.A., Fineschi, S., Grivet, D., Lascoux, M., Mohanty, A., Müller-Starck, G., Musch, B., Palme, A., Martin Clemente, J.P., Rendell, S. \& Vendramin, G.G. (2003) Glacial refugia: hotspots but not melting pots of genetic diversity. Science, 300, 1563-1565.

Petit, R.J., Bialozyt, R., Garnier-Gére, P. \& Hampe, A. (2004) Ecology and genetics of tree invasions: from recent introductions to Quaternary migrations. Forest Ecology and Management, 197, 117-137.

Pons, O. \& Petit, R.J. (1995) Estimation, variance and optimal sampling of gene diversity. I. Haploid locus. Theoretical and Applied Genetics, 90, 462-470.

Pons, O. \& Petit, R.J. (1996) Measuring and testing genetic differentiation with ordered versus unordered alleles. Genetics, 144, 1237-1245.

Rendell, S. \& Ennos, R.A. (2002) Chloroplast DNA diversity in Calluna vulgaris (heather) populations in Europe. Molecular Ecology, 11, 69-78.

Rendell, S. \& Ennos, R.A. (2003) Chloroplast DNA diversity of the dioecious European tree Ilex aquifolium L. (English holly). Molecular Ecology, 12, 2681-2688.

Silvertown, J. \& Dodd, M. (1996) Comparing plants and connecting traits. Philosophical Transactions of the Royal Society of London Series B, 351, 1233-1239.

Soltis, D.E., Soltis, P.S., Chase, M.W., Mort, M.E., Albach, D.C., Zanis, M., Savolainen, V., Hahn, W.H., Hoot, S.B., Fay, M.F., Axtell, M., Swensen, S.M., Prince, L.M., Kress, W.J., Nixon, K.C. \& Farris, J.S. (2000) Angiosperm phylogeny inferred from $18 \mathrm{~S}$ rDNA, rbcL, and atpB sequences. Botanical Journal of the Linnean Society, 133, 381-461.

Soltis, P.S., Soltis, D.E. \& Chase, M.W. (1999) Angiosperm phylogeny inferred from multiple genes as a tool for comparative biology. Nature, 402, 402-404.

Svenning, J-C. (2003) Deterministic Plio-Pleistocene extinctions in the European cool-temperate tree flora. Ecology Letters, 6, 646-653.

Tutin, T.G., Heywood, V.H., Burges, N.A., Valentine, D.H., Walters, S.M. \& Webb, D.A. (1964-80) Flora Europaea. Cambridge University Press, Cambridge, UK.

Westoby, M. (1998) A leaf-height-seed (LHS) plant ecology strategy scheme. Plant and Soil, 199, 213-227.

Willis, K.J. \& Niklas, K.J. (2004) The role of Quaternary environmental change in plant macroevolution: the exception or the rule? Philosophical Transactions of the Royal Society of London Series B, 359, 159-172. 


\section{BIOSKETCHES}

This paper is a contribution resulting from the EU FAIR project CYTOFOR on the comparative phylogeography of woody plants in Europe, coordinated by Rémy Petit, Director of Research at INRA Bordeaux, which involved nine laboratories, mostly interested in plant population genetics. One of these laboratories is that of ETSIA in Madrid, lead by Itziar Aguinagalde and Juan Pedro Martín. Aparajita Mohanty held a 3-year postdoctoral research post at ETSIA as part of this EU project, working with Prunus avium and Prunus spinosa. Arndt Hampe is interested in ecological, population genetic and evolutionary aspects of plant dispersal and recruitment processes. He has recently completed his $\mathrm{PhD}$ thesis in Sevilla on the reproductive biology, demography and Quaternary phylogeography of the bird-dispersed shrub Frangula alnus (Rhamnaceae). He participated in that work while visiting the INRA group in Bordeaux. Jérôme Duminil is a PhD student at INRA working on meta-analyses of studies of genetic diversity.

Editor: Philip Stott 